\title{
The Renin-Angiotensin System in the Pathophysiology of Type 2 Diabetes
}

\author{
Gijs H. Goossens
}

Department of Human Biology, NUTRIM School for Nutrition, Toxicology \& Metabolism, Maastricht University Medical Center, Maastricht, the Netherlands

\section{Key Words}

Renin-angiotensin system • Insulin secretion • Insulin resistance • Skeletal muscle • Adipose tissue

\begin{abstract}
Increased activation of the renin-angiotensin system (RAS) has been related to cardiovascular disease and type 2 diabetes mellitus. Most randomized clinical trials have demonstrated that RAS blockade reduces the incidence of type 2 diabetes, which has been explained by improved insulin secretion and insulin sensitivity. In this review, an overview of the mechanisms that may underlie the association between the RAS and type 2 diabetes will be provided, with focus on skeletal muscle and adipose tissue function. This will include discussion of several human studies performed in our laboratory to investigate the metabolic and hemodynamic effects of the RAS, combining in vivo measurements of whole-body and tissue metabolism with molecular and immunohistochemical approaches. Available data suggest that the detrimental effects of the RAS on insulin secretion are mediated by a reduction in pancreatic blood flow and induction of islet fibrosis, oxidative stress as well as inflammation, whereas both impaired skeletal muscle function and adipose tissue dysfunction may underlie RAS-induced insulin resistance. Thus, although future studies in humans are warranted, current evidence supports that targeting the RAS in intervention studies may improve metabolic and cardiovascular function in conditions of insulin resistance like obesity and type 2 diabetes.
\end{abstract}

Copyright $\odot 2012$ S. Karger GmbH, Freiburg 
Goossens et al.: The Renin-Angiotensin System in the Pathophysiology of Type 2 Diabetes

\section{Introduction}

Two key features in the pathogenesis of type 2 diabetes are insulin resistance (a decreased ability of insulin to stimulate peripheral glucose uptake) [1] and beta-cell failure (inability of the pancreatic beta-cells to adequately secrete insulin) [2]. Although it is well established that abdominal obesity is a major risk factor for chronic diseases, the mechanisms underlying obesity-related type 2 diabetes are not yet fully understood. However, progress has been made regarding the identification of underlying mechanisms as well as approaches to prevent, delay, or treat type 2 diabetes over the past few years.

Obesity is characterized by increased activation of the renin-angiotensin system (RAS), as has been reviewed extensively [3, 4]. Interestingly, the RAS has been linked to obesityrelated chronic diseases. More specific, the RAS has been established as a major determinant of cardiovascular disease [5-7]. In addition, multiple lines of evidence suggest that increased activation of the RAS is involved in the development of type 2 diabetes [3, 8-10]. In agreement with the latter, a meta-analysis of comparative outcome trials [11] has shown that RAS blockade, using either angiotensin (Ang) II type 1 receptor blockers (ARBs) or angiotensin-converting enzyme inhibitors (ACEi), reduced the incidence of new-onset type 2 diabetes by $22 \%$ in high-risk populations. More recently, the prospective NAVIGATOR trial [12] has also shown that treatment with the ARB valsartan (median follow-up 5 years), in addition to lifestyle modification, reduced type 2 diabetes incidence by $14 \%$ in subjects with impaired glucose homeostasis. However, the prospective DREAM trial [13] showed somewhat conflicting results. In this trial, ACEi treatment (median follow-up 3 years) non-significantly reduced the incidence of type 2 diabetes by $9 \%$ compared with placebo in subjects with impaired glucose homeostasis but without cardiovascular disease. However, ACEi treatment significantly increased regression to normoglycemia and reduced 2-hour glucose concentrations compared with placebo [13]. Importantly, differences in study design, population, and treatment duration may underlie the less convincing effects of ACEi on the onset of type 2 diabetes in the DREAM trial. Nevertheless, most randomized clinical trials indicate that RAS blockade may protect against the development of type 2 diabetes in humans. The beneficial effects of RAS blockade in the prevention of type 2 diabetes have been explained both by improved insulin sensitivity and insulin secretion $[3,8,9]$.

In this review, an overview of the mechanisms that underlie the relation between disproportionate activation of the RAS and type 2 diabetes will be provided, with focus on mechanisms related to insulin sensitivity. This will include the discussion of several human studies performed in our laboratory, in which whole-body and tissue physiology were studied in vivo in humans, using techniques like arterio-venous balance measurements across adipose tissue (AT) and skeletal muscle, tissue blood flow measurements, microdialysis and hyperinsulinemic-euglycemic and hyperglycemic clamps, in combination with molecular and immunohistochemical approaches to examine the metabolic and hemodynamic effects of Ang II - the main effector molecule of the RAS - and RAS blockade.

\section{The Renin-Angiotensin System and Beta-Cell Function}

Obesity and physical inactivity are major risk factors for the development of insulin resistance and type 2 diabetes. The decline in insulin sensitivity imposes progressive stress on the compromised beta-cell. At a certain stage, insulin secretion becomes insufficient to maintain normoglycemia, and glucose concentrations start to rise into the prediabetic range, resulting in impaired fasting glucose (IFG) and/or impaired glucose tolerance (IGT) [14]. Beta-cell failure is a prerequisite in the development for type 2 diabetes, and a deterio- 
ration of beta-cell function as well as loss of functional beta-cell mass are important determinants of disease progression $[2,15]$.

Evidence suggests that the RAS may contribute to an impaired insulin secretion $[9,16$, 17]. In rodents, Ang II decreased pancreatic islet blood flow, which could lead to a reduced insulin release by the beta-cells $[9,17]$, whereas RAS blockade enhanced pancreatic blood flow $[18,19]$. In addition to the systemic RAS, which is known for its classical effects on blood pressure, electrolyte and fluid homeostasis [20,21], RAS components have been identified in many tissues, including the kidney, heart, brain, nerve fibers, reproductive organs, blood vessels, liver, skeletal muscle, AT, and pancreas [3]. Thus, it may well be that the pancreatic RAS also directly affects beta-cell function and mass. Indeed, in vitro and in vivo studies performed in rodents have shown that the RAS induced islet fibrosis, oxidative stress, inflammation, and impaired insulin secretion, whereas RAS blockade with an ACEi or ARB improved islet morphology and function and increased glucose tolerance [22-28].

Notwithstanding the extensive data derived from animal studies, evidence in humans is limited. Incubation of isolated human pancreatic islets with an ACEi counteracted several of the deleterious effects of high-glucose exposure, including reduction of insulin secretion and increased oxidative stress [29]. In vivo, it has been demonstrated that treatment with the ARB candesartan (8 mg daily for 3 months) or ACEi captopril (mean dose $81 \pm 12 \mathrm{mg}$ daily for 4 months) increased early-phase insulin secretion in patients with essential hypertension and impaired glucose tolerance [30,31], although treatment with the ARB valsartan (80 mg twice daily) for 6 weeks [32] or the ACEi ramipril (up to $15 \mathrm{mg}$ daily) for 3 years [33] did not improve beta-cell function. In addition to other methodological issues, the dosage used and treatment duration may explain these conflicting findings. Very recently, we have performed a randomized, placebo-controlled, double-blind study to investigate the effects of long-term treatment with the ARB valsartan (320 mg daily) on beta-cell function in subjects with impaired glucose metabolism. We demonstrated that valsartan treatment for 26 weeks improved both first-phase and second-phase insulin secretion, assessed by a hyperglycemic-clamp, compared with placebo [34]. Collectively, available data indicate that the pancreatic islet RAS may, at least in part, be responsible for impaired insulin secretion, and RAS blockade may be a promising strategy to enhance insulin secretion in subjects at high risk of developing type 2 diabetes.

\section{The Renin-Angiotensin System and Insulin Sensitivity}

Although several clinical studies have shown beneficial effects of RAS blockade on insulin sensitivity in humans [30, 35-43], conflicting data have also been reported [44-53]. Unfortunately, many of these investigations are based on uncontrolled study designs and surrogate markers of insulin sensitivity, and are potentially confounded by the use of additional medication. Therefore, we performed a double-blind, placebo-controlled, randomized trial to examine the effects of ACE inhibitor treatment on insulin sensitivity, as assessed by a hyperinsulinemic-euglycemic clamp, in obese insulin resistant subjects. We demonstrated that treatment with the ACE inhibitor ramipril ( $5 \mathrm{mg}$ daily) for 2 weeks had no significant effects on whole-body insulin sensitivity [54]. Our findings are consistent with evidence from other well-designed trials in nondiabetic hypertensive patients [53] and in type 2 diabetic patients with hypertension $[47,48]$, showing no beneficial effect of short-term ACE inhibitor treatment on insulin sensitivity. Thus, in humans, evidence for beneficial effects of short-term RAS blockade on insulin sensitivity is controversial. However, dosage and treatment duration may be important factors determining study outcome. This is supported by recent findings from our group, demonstrating that treatment with the ARB valsartan 
(320 mg daily) for 26 weeks significantly improved insulin sensitivity compared with placebo in subjects with impaired glucose metabolism [34].

As stated above, RAS components are present in a variety of tissues playing a major role in the etiology of insulin resistance and type 2 diabetes. We discussed several years ago that the RAS may exert detrimental effects in skeletal muscle and AT, which in turn may contribute to insulin resistance [3]. Thus, the beneficial effects of long-term RAS blockade on insulin sensitivity may be mediated by improved skeletal muscle and AT function. In the following paragraphs, an up-to-date overview of studies that have investigated the effects of the RAS on skeletal muscle and AT function in relation to insulin sensitivity will be provided.

\section{The Renin-Angiotensin System and Skeletal Muscle Function}

Skeletal muscle is a major tissue in the etiology of insulin resistance, as it accounts for more than $80 \%$ of insulin-stimulated glucose disposal [55]. The RAS may induce impairments in skeletal muscle metabolism through effects on tissue perfusion, skeletal muscle insulin signaling and mitochondrial function.

\section{Skeletal Muscle Blood Flow}

The vascular system controls the delivery of nutrients and hormones to skeletal muscle. Therefore, skeletal muscle blood flow may regulate tissue metabolism and contractile performance. In addition to total blood flow, expansion of the endothelial surface area available for exchange of nutrients through the recruitment of additional microvasculature within the muscle may enhance nutrient delivery to the tissue and may be an important factor that determines skeletal muscle glucose uptake [56]. Indeed, it has been demonstrated that impaired insulin-mediated capillary recruitment, as seen in obesity and insulin resistance [57, 58], may contribute to reduced glucose uptake in vivo [59-62].

Since the RAS is one of the major mechanisms regulating vascular tone [20,21], we hypothesized that Ang II may reduce skeletal muscle blood flow in humans, which in turn may contribute to reduced glucose uptake. Indeed, we found that local administration of Ang II into the gastrocnemius muscle by microdialysis markedly decreased local blood flow in lean and obese subjects [63]. In line, chronic RAS blockade increased postprandial forearm blood flow in subjects with type 2 diabetes [64], and both acute and chronic RAS blockade prevented or improved skeletal muscle microvascular dysfunction in rats [65-67]. However, we did not find an increase in basal and insulin-stimulated total forearm blood flow after 2 weeks ACEi treatment in obese insulin resistant subjects [54]. It should be mentioned that we did not assess capillary recruitment in the latter study. To summarize, the majority of available data suggest that the RAS is involved in the regulation of skeletal muscle blood flow (total blood flow and/or capillary recruitment), although the quantitative contribution of RAS-induced impairments in skeletal muscle blood flow to overall insulin and glucose homeostasis in states of insulin resistance remains to be established.

\section{Skeletal Muscle Insulin Signaling}

Evidence from cell experiments and animal studies indicate that the RAS may directly impair insulin signaling. It has been shown that the heterozygous TG(mREN2)27 rat, harboring the mouse transgene for renin, was characterized by increased Ang II concentrations and insulin resistance, which could be attributed to specific defects in the insulinsignaling pathway in skeletal muscle [68]. In agreement with these findings, both acute and chronic RAS blockade increased protein expression of glucose-transporter 4 (GLUT4) and decreased insulin resistance in obese Zucker rats [8]. Bradykinin accumulation caused by 
ACE inhibitor treatment may also contribute to the benefical effects on glucose metabolism. For example, it has been demonstrated that bradykinin increased basal and insulin-stimulated glucose uptake in skeletal muscle of insulin resistant obese Zucker rats [69, 70], possibly by improving post-receptor insulin signaling and enhancing GLUT4 translocation to the cell membrane [70].

Furthermore, it has been shown that Ang II infusion induced insulin resistance in rats, which could, however, not been attributed to impairment in early steps of insulin signaling [71]. Rather, increased oxidative stress, possibly through impaired insulin signaling located downstream from phosphatidylinositol (PI) 3 kinase activation, seems to be involved in Ang II-induced insulin resistance [71]. In line, in vivo treatment with the ARB valsartan reduced oxidative stress, NF- $\mathrm{KB}$ activation and TNF- $\alpha$ expression in skeletal muscle of the TG(mREN2)27 rat [72]. In the same study, Ang II treatment of L6 myotubes induced NF- $\kappa B$ activation and TNF- $\alpha$ production and decreased insulin-stimulated Akt activation and GLUT4 translocation, effects that were markedly diminished by the ARB valsartan [72].

Blockade of RAS via direct inhibition of the rate-limiting enzyme renin, thereby reducing the conversion of angiotensinogen to Ang I, leading to decreased Ang II concentrations, may provide more potent RAS blockade compared with ACEi or ARBs. The effects of direct renin inhibition, or inhibition of aldosterone effects using mineralocorticoid receptor blockade, on glucose metabolism and the onset of type 2 diabetes may be different from treatment with ACEi and/or ARBs. Direct renin inhibition and mineralocorticoid receptor blockade has been shown to improve insulin sensitivity and skeletal muscle glucose uptake in obese Zucker rats [73], transgenic (mRen2)27 rats [74, 75], and diabetic mice [76, 77]. At the moment, however, no clinical data is available yet regarding the effect of these drugs on glucose metabolism in humans. Thus, additional outcome trials are needed to establish the role of these novel classes of antihypertensive drugs, alone or in combination with ACEi or ARBs, in the prevention of type 2 diabetes.

In summary, several lines of evidence suggest that the RAS may contribute to impaired insulin signaling in skeletal muscle, either directly or via induction of oxidative stress and NF- $\kappa \mathrm{B}$ activation in this tissue. Until now, however, human studies examining the effects of Ang II and RAS blockade on skeletal muscle insulin signaling have not been performed.

\section{Mitochondrial Function}

Mitochondrial dysfunction in skeletal muscle has been suggested to underlie the development of insulin resistance and type 2 diabetes, although it should be explicitly mentioned that a number of recent studies question whether reduced mitochondrial function is a primary factor in the pathophysiology of these disorders [78]. Increased skeletal muscle mitochondrial reactive oxygen species (ROS) have been implicated in mitochondrial dysfunction and insulin resistance [79-81]. Interestingly, it has been shown that Ang II increased mitochondrial ROS, decreased the expression of genes involved in mitochondrial biogenesis, and reduced mitochondrial content and membrane potential in C2C12 myocytes, whereas RAS blockade reversed these effects [82]. Furthermore, chronic Ang II infusion in mice reduced muscle mitochondrial content, increased intramuscular triacylglycerol (TAG) content and deteriorated glycemic control. RAS blockade was able to partially reverse the reduction in mitochondrial content, which was associated with an increased fat oxidation, a decreased intramuscular TAG content, and an improved glucose tolerance [82]. Nevertheless, data in humans are scarce. We have shown that 2 weeks ACEi treatment had no effect on whole-body substrate oxidation and intramuscular TAG content [54]. Clearly, more human in vitro studies and long-term clinical trials are needed to examine the importance of the RAS in skeletal muscle metabolism. Currently, we are investigating the effects of longterm RAS blockade on skeletal muscle fatty acid handling in subjects with impaired glucose 
metabolism, using a dual stable isotope approach in combination with measurements of arterio-venous concentration differences across forearm muscle and forearm blood flow, enabling differentiation between the metabolic fate of dietary versus endogenous fatty acids. In addition, skeletal muscle biopsies will allow assessment of RAS blockade-induced effects on intramuscular lipid metabolism.

\section{The Renin-Angiotensin System and Adipose Tissue Function}

Converging evidences suggest that AT dysfunction, rather than abdominal fat mass per se, plays a crucial role in the development and progression of insulin resistance and type 2 diabetes [83]. Adipocyte hyperthrophy, macrophage infiltration, inflammation, and an impaired AT blood flow (ATBF) are important aspects of AT dysfunction that are associated with insulin resistance, as reviewed [83].

In humans, different RAS components have been identified in AT [84-89]. We have measured arterio-venous concentration differences of Ang II and its precursor, angiotensinogen (AGT), across abdominal subcutaneous AT in combination with measurements of ATBF in lean and obese subjects under baseline conditions and during beta-adrenergic stimulation, and have shown that locally produced Ang II in AT was not secreted into the circulation in these subjects [90]. However, AGT was released from AT during beta-adrenergic stimulation in obese subjects, which may have contributed to increased plasma Ang II concentrations [90]. Together, these data suggest that the RAS in AT may exert autocrine, paracrine, and endocrine effects. Indeed, substantial evidence suggests that disturbances in the RAS may impair AT function via multiple mechanisms, which together may contribute to the development of insulin resistance, as discussed below.

\section{Adipocyte Size}

Hyperthrophic adipocytes in obese and prediabetic individuals as well as in patients with type 2 diabetes have been observed by many investigators [91-94]. In fact, enlargement of abdominal subcutaneous adipocyte size appears to be an independent determinant of insulin resistance and type 2 diabetes [94,95]. A reduced buffering capacity for lipid storage in hyperthrophic adipocytes, leading to lipid overflow in the circulation and ectopic fat deposition, as well as increased production of pro-inflammatory cytokines by enlarged adipocytes seem to underlie the association between adipocyte size and insulin resistance $[83,96]$.

The enlargement of adipocytes may represent a failure in the recruitment of new adipocytes due to impaired differentiation, which is a precipitating factor in the etiology type 2 diabetes $[93,94]$. Cell experiments and studies in rodents indicate that the Ang II may inhibit adipocyte differentiation, which may contribute to enlargement of existing adipocytes. Conversely, RAS blockade has been found to reduce adipocyte size [97-101]. In line, we have recently shown that long-term ARB treatment markedly decreased abdominal subcutaneous adipocyte size, with a shift towards a higher frequency of small adipocytes, compared with placebo in subjects with impaired glucose metabolism [102]. Interestingly, it has been demonstrated that some ARBs show partial peroxisome proliferator-activated receptorgamma (PPAR $\gamma$ ) agonistic activity in vitro, which may contribute to increased adipocyte differentiation $[103,104]$. Telmisartan is the most potent and only ARB to show activation of PPAR $y$ at concentrations achievable in the plasma with normal oral dosing [104]. However, studies in subjects with the metabolic syndrome or diabetes comparing telmisartan with different comparators, including other ARBs, could not demonstrate a consistent superiority regarding improvement of glucose metabolism by telmisartan [105]. 
Important processes in the regulation of adipocyte size, in addition to adipocyte differentiation, include the storage and release of fatty acids. Ang II stimulation increased lipid synthesis and storage in 3T3-L1 and human adipocytes [106]. Moreover, recent in vitro experiments have demonstrated that Ang II decreased, whereas RAS blockade increased gene/protein expression and activity of lipoprotein lipase, an enzyme that increases TAG clearance by AT [98]. Furthermore, we [63] and others [107, 108] have shown that local Ang II administration in abdominal subcutaneous AT by microdialysis decreased AT lipolysis in vivo in humans. We confirmed and extended these findings by demonstrating that Ang II modestly but dose-dependently reduced lipolysis in human isolated adipocytes, an effect that was completely abolished by Ang II type 1 receptor blockade [109]. These Ang II-induced effects may, theoretically, contribute to adipocyte enlargement. However, conflicting data with respect to RAS effects on AT lipolysis have also been reported [110-112]. Taken together, the RAS may affect adipocyte size through effects on adipocyte differentiation and AT lipid metabolism, thereby potentially modulating the lipid storage capacity of adipocytes, the inflammatory phenotype of AT and, as a consequence, insulin sensitivity.

\section{Adipose Tissue Inflammation}

AT macrophage infiltration and inflammation are important hallmarks of obesity, insulin resistance, and type 2 diabetes [83]. Adipocyte size is an important determinant of adipokine expression and secretion, with a shift toward dominance of proinflammatory adipokine secretion by large adipocytes [83].

Interestingly, it has been demonstrated that Ang II increased, whereas RAS blockade decreased AT gene expression of inflammatory markers, thereby affecting glucose homeostasis in rodents $[23,25,99-101,113,114]$. As mentioned above, we have recently found that treatment with the ARB valsartan for 26 weeks reduced abdominal subcutaneous adipocyte size compared with placebo in subjects with impaired glucose metabolism [102]. This may lead to beneficial alterations in AT gene expression and secretion of inflammatory cell markers. Indeed, we have recently demonstrated that the valsartan-induced decrease in adipocyte size was associated with reduced expression of macrophage infiltration markers in human AT [102]. The reduction in AT gene expression of inflammatory cell markers after RAS blockade may in turn translate into alterations in circulating adipokines. Indeed, several studies have shown that ARB treatment increased circulating adiponectin concentrations [115-119]. In contrast, ARB treatment had no effects on circulating leptin, TNF- $\alpha$ and adiponectin, despite increased insulin sensitivity [120]. These apparently conflicting findings may be explained by differences in study population, since in several of these positive studies patients with essential hypertension, the metabolic syndrome, and/or increased systemic inflammation participated. Taken together, Ang II seems to contribute to AT inflammation, at least in rodents. As such, long-term RAS blockade may improve AT inflammation, thereby enhancing insulin sensitivity. More human studies are needed to examine the effects of RAS blockade on AT inflammation and circulating concentrations of adipokines that have been linked to insulin sensitivity.

\section{Adipose Tissue Blood Flow}

We and others have shown that both fasting ATBF and the postprandial increase in ATBF are decreased in obese, insulin resistant, and type 2 diabetic subjects [90, 91, 121-124]. Interestingly, an impaired ATBF response to nutrient intake is closely associated with insulin resistance $[91,122,123]$.

One of the explanations for this relationship may be that a decreased ATBF negatively affects the AT lipid buffering capacity via a reduction of TAG clearance [125] and increased re-esterification of non-esterified fatty acids [126], resulting in an excessive flux of lipids 
toward non-ATs (ectopic fat storage) and, as a consequence, insulin resistance [83]. Alternatively, it has been postulated that an impaired ATBF may lead to a relative oxygen deficit in certain parts of AT ('AT hypoxia') [83, 127]. Indeed, we have demonstrated for the first time that ATBF is an important regulator of $\mathrm{AT} \mathrm{PO}_{2}$ in humans [91]. Experiments in 3T3-L1 [128130 ] and human adipocytes [131] suggest that low oxygen availability $\left(1 \% \mathrm{O}_{2}\right)$ may adversely affect the expression of adipokines, with a shift towards a pro-inflammatory phenotype. However, in marked contrast with previous studies in obese mice $[129,132]$ and humans $[133$,

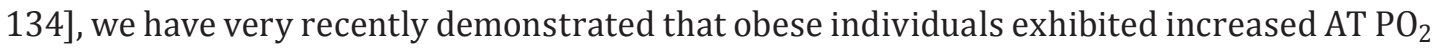
despite lower ATBF, which was accompanied by insulin resistance and AT inflammation [91]. Clearly, more studies in humans are needed to examine the role of $\mathrm{AT}^{\mathrm{PO}_{2}}$ in metabolic disease.

Using both microdialysis and microinfusion approaches, we have demonstrated that Ang II decreases ATBF $[63,121]$ and that local blockade of the Ang II type 1 receptor in abdominal subcutaneous AT markedly increases ATBF in humans [121]. Furthermore, we have shown that treatment with the ARB valsartan for 26 weeks increased both fasting and postprandial ATBF compared with placebo [102], which may have contributed to the valsartan-induced increase in insulin sensitivity [34].

\section{Conclusions}

Several in vitro, animal, and clinical studies have demonstrated that the RAS may contribute to impaired insulin secretion and insulin resistance, thereby increasing the risk for type 2 diabetes. Detrimental effects of the RAS on insulin secretion seem to be mediated by a reduction in pancreatic blood flow and induction of islet fibrosis, oxidative stress, and inflammation, whereas both impaired skeletal muscle function (disturbances in skeletal muscle blood flow, insulin signaling, and mitochondrial function) and AT dysfunction (adipocyte hyperthrophy, inflammation, and impairments in ATBF and lipid metabolism) may underlie RAS-induced insulin resistance. Thus, the reduced incidence of new-onset type 2 diabetes following long-term treatment with ACEi or ARBs in high-risk individuals seems to involve beneficial effects on the pancreas, skeletal muscle, and AT. Collectively, the studies described in this review support that targeting the RAS in intervention studies improves metabolic and cardiovascular function in conditions of insulin resistance like obesity and type 2 diabetes. However, more clinical studies in humans at high risk of developing type 2 diabetes are warranted.

\section{Acknowledgements}

The author is grateful to the colleagues who have contributed to the studies described in this article, particularly Prof. Ellen E. Blaak, Prof. Marleen A. van Baak, Prof. Wim H.M. Saris, Chantalle C.M. Moors, Dr. Johan W.E. Jocken, Ellen Konings and Yvonne Essers (Department of Human Biology, Maastricht University Medical Centre, The Netherlands), Prof. Keith N. Frayn, Dr. Fredrik Karpe (Oxford Centre for Diabetes, Endocrinology and Metabolism, University of Oxford, UK), Prof. Peter Arner (Karolinska Institute, Stockholm, Sweden), Prof. Michaela Diamant, Dr. Nynke J. van der Zijl (VU University Medical Centre, Amsterdam, The Netherlands), Prof. Volker Ribitsch (Joanneum Research Institute, Graz, Austria) and Prof. Karine Clément (INSERM, Nutriomique U872 (Eq 7); University Pierre et Marie Curie-Paris 6, Cordelier Research Centre; Human Nutrition Research Centre; Assistance Publique-Hôpitaux de Paris, Pitié-Salpêtrière hospital Paris, France).

The author also thanks the Dutch Diabetes Research Foundation (grant No. 2008.11.010), Dutch Top Institute Pharma (project T1-201), Top Institute Food and Nutrition (project A-009), the Netherlands Organization for Scientific Research and the European Association for the Study of Obesity for financial support. 
Goossens et al.: The Renin-Angiotensin System in the Pathophysiology of Type 2 Diabetes

\section{Disclosure Statement}

The author declared no conflicts of interest.

\section{References}

1 Reaven GM: Banting lecture 1988. Role of insulin resistance in human disease. Diabetes 1988;37:15951607.

2 Porte D Jr: Banting lecture 1990. Beta-cells in type II diabetes mellitus. Diabetes 1991;40:166-180.

- 3 Goossens GH, Blaak EE, van Baak MA: Possible involvement of the adipose tissue renin-angiotensin system in the pathophysiology of obesity and obesity-related disorders. Obes Rev 2003;4:43-55.

- 4 Engeli S, Negrel R, Sharma AM: Physiology and pathophysiology of the adipose tissue renin-angiotensin system. Hypertension 2000;35:1270-1277.

- 5 Ferrario CM, Strawn WB: Role of the renin-angiotensin-aldosterone system and proinflammatory mediators in cardiovascular disease. Am J Cardiol 2006;98:121-128.

- 6 Kim S, Iwao H: Molecular and cellular mechanisms of angiotensin II-mediated cardiovascular and renal diseases. Pharmacol Rev 2000;52:11-34.

- 7 Unger T: The role of the renin-angiotensin system in the development of cardiovascular disease. Am J Cardiol 2002;89:3A-9A; discussion 10A.

- 8 Henriksen EJ: Improvement of insulin sensitivity by antagonism of the renin-angiotensin system. Am J Physiol Regul Integr Comp Physiol 2007;293:R974-980.

9 Leung PS: Mechanisms of protective effects induced by blockade of the renin-angiotensin system: novel role of the pancreatic islet angiotensin-generating system in type 2 diabetes. Diabet Med 2007;24:110-116.

-10 Olivares-Reyes JA, Arellano-Plancarte A, Castillo-Hernandez JR: Angiotensin II and the development of insulin resistance: implications for diabetes. Mol Cell Endocrinol 2009;302:128-139.

-11 Gillespie EL, White CM, Kardas M, Lindberg M, Coleman CI: The Impact of ACE inhibitors or angiotensin II Type 1 receptor blockers on the development of new-onset type 2 diabetes. Diabetes Care 2005;28:22612266.

-12 McMurray JJ, Holman RR, Haffner SM, Bethel MA, Holzhauer B, Hua TA, Belenkov Y, Boolell M, Buse JB, Buckley BM, Chacra AR, Chiang FT, Charbonnel B, Chow CC, Davies MJ, Deedwania P, Diem P, Einhorn D, Fonseca V, Fulcher GR, Gaciong Z, Gaztambide S, Giles T, Horton E, Ilkova H, Jenssen T, Kahn SE, Krum H, Laakso M, Leiter LA, Levitt NS, Mareev V, Martinez F, Masson C, Mazzone T, Meaney E, Nesto R, Pan C, Prager R, Raptis SA, Rutten GE, Sandstroem H, Schaper F, Scheen A, Schmitz O, Sinay I, Soska V, Stender S, Tamas G, Tognoni G, Tuomilehto J, Villamil AS, Vozar J, Califf RM: Effect of valsartan on the incidence of diabetes and cardiovascular events. N Engl J Med 2010;362:1477-1490.

13 Bosch J, Yusuf S, Gerstein HC, Pogue J, Sheridan P, Dagenais G, Diaz R, Avezum A, Lanas F, Probstfield J, Fodor G, Holman RR: Effect of ramipril on the incidence of diabetes. N Engl J Med 2006;355:1551-1562.

-14 Kahn SE: The relative contributions of insulin resistance and beta-cell dysfunction to the pathophysiology of type 2 diabetes. Diabetologia 2003;46:3-19.

15 Kahn CR: Medicine. Can we nip obesity in its vascular bud? Science 2008;322:542-543.

16 Tikellis C, Cooper ME, Thomas MC: Role of the renin-angiotensin system in the endocrine pancreas: implications for the development of diabetes. Int J Biochem Cell Biol 2006;38:737-751.

-17 Carlsson PO: The renin-angiotensin system in the endocrine pancreas. JOP 2001;2:26-32.

-18 Huang Z, Jansson L, Sjoholm A: Pancreatic islet blood flow is selectively enhanced by captopril, irbesartan and pravastatin, and suppressed by palmitate. Biochem Biophys Res Commun 2006;346:26-32.

19 Kampf C, Lau T, Olsson R, Leung PS, Carlsson PO: Angiotensin II type 1 receptor inhibition markedly improves the blood perfusion, oxygen tension and first phase of glucose-stimulated insulin secretion in revascularised syngeneic mouse islet grafts. Diabetologia 2005;48:1159-1167.

20 Peach MJ: Renin-angiotensin system: biochemistry and mechanisms of action. Physiol Rev 1977;57:313370.

-21 Timmermans PB, Wong PC, Chiu AT, Herblin WF, Benfield P, Carini DJ, Lee RJ, Wexler RR, Saye JA, Smith RD: Angiotensin II receptors and angiotensin II receptor antagonists. Pharmacol Rev 1993;45:205-251.

22 Yuan L, Li X, Li J, Li HL, Cheng SS: Effects of renin-angiotensin system blockade on the islet morphology and function in rats with long-term high-fat diet. Acta Diabetol 2010; DOI: 10.1007/s00592-010-0210-8.

-23 Chu KY, Lau T, Carlsson PO, Leung PS: Angiotensin II type 1 receptor blockade improves beta-cell function and glucose tolerance in a mouse model of type 2 diabetes. Diabetes 2006;55:367-374.

-24 Shao J, Iwashita N, Ikeda F, Ogihara T, Uchida T, Shimizu T, Uchino H, Hirose T, Kawamori R, Watada H: Beneficial effects of candesartan, an angiotensin II type 1 receptor blocker, on beta-cell function and morphology in db/db mice. Biochem Biophys Res Commun 2006;344:1224-1233.

25 Cole BK, Keller SR, Wu R, Carter JD, Nadler JL, Nunemaker CS: Valsartan protects pancreatic islets and adipose tissue from the inflammatory and metabolic consequences of a high-fat diet in mice. Hypertension 2010;55:715-721. 
Goossens et al.: The Renin-Angiotensin System in the Pathophysiology of Type 2 Diabetes

26 Tikellis C, Wookey PJ, Candido R, Andrikopoulos S, Thomas MC, Cooper ME: Improved islet morphology after blockade of the renin- angiotensin system in the ZDF rat. Diabetes 2004;53:989-997.

27 Lau T, Carlsson PO, Leung PS: Evidence for a local angiotensin-generating system and dose-dependent inhibition of glucose-stimulated insulin release by angiotensin II in isolated pancreatic islets. Diabetologia 2004;47:240-248.

-28 Ko SH, Kwon HS, Kim SR, Moon SD, Ahn YB, Song KH, Son HS, Cha BY, Lee KW, Son HY, Kang SK, Park CG, Lee IK, Yoon KH: Ramipril treatment suppresses islet fibrosis in Otsuka Long-Evans Tokushima fatty rats. Biochem Biophys Res Commun 2004;316:114-122.

29 Lupi R, Del Guerra S, Bugliani M, Boggi U, Mosca F, Torri S, Del Prato S, Marchetti P: The direct effects of the angiotensin-converting enzyme inhibitors, zofenoprilat and enalaprilat, on isolated human pancreatic islets. Eur J Endocrinol 2006;154:355-361.

-30 Pollare T, Lithell H, Berne C: A comparison of the effects of hydrochlorothiazide and captopril on glucose and lipid metabolism in patients with hypertension. N Engl J Med 1989;321:868-873.

-31 Suzuki K, Nakagawa 0, Aizawa Y: Improved early-phase insulin response after candesartan treatment in hypertensive patients with impaired glucose tolerance. Clin Exp Hypertens 2008;30:309-314.

-32 Bokhari S, Israelian Z, Schmidt J, Brinton E, Meyer C: Effects of angiotensin II type 1 receptor blockade on beta-cell function in humans. Diabetes Care 2007;30:181.

-33 Hanley AJ, Zinman B, Sheridan P, Yusuf S, Gerstein HC: Effect of Rosiglitazone and Ramipril on $\beta$-cell function in people with impaired glucose tolerance or impaired fasting glucose: the DREAM trial. Diabetes Care 2010;33:608-613.

34 van der Zijl NJ, Moors CC, Goossens GH, Hermans MM, Blaak EE, Diamant M: Valsartan Improves $\beta$-cell function and insulin sensitivity in subjects with impaired glucose metabolism: a randomized controlled trial. Diabetes Care 2011;34:845-851.

-35 Jauch KW, Hartl W, Guenther B, Wicklmayr M, Rett K, Dietze G: Captopril enhances insulin responsiveness of forearm muscle tissue in non-insulin-dependent diabetes mellitus. Eur J Clin Invest 1987;17:448-454.

-36 Lender D, Arauz-Pacheco C, Breen L, Mora-Mora P, Ramirez LC, Raskin P: A double blind comparison of the effects of amlodipine and enalapril on insulin sensitivity in hypertensive patients. Am J Hypertens 1999; 12:298-303.

-37 Morel Y, Gadient A, Keller U, Vadas L, Golay A: Insulin sensitivity in obese hypertensive dyslipidemic patients treated with enalapril or atenolol. J Cardiovasc Pharmacol 1995;26:306-311.

-38 Paolisso G, Gambardella A, Verza M, D’Amore A, Sgambato S, Varricchio M: ACE inhibition improves insulinsensitivity in aged insulin-resistant hypertensive patients. J Hum Hypertens 1992;6:175-179.

-39 Shamiss A, Carroll J, Peleg E, Grossman E, Rosenthal T: The effect of enalapril with and without hydrochlorothiazide on insulin sensitivity and other metabolic abnormalities of hypertensive patients with NIDDM. Am J Hypertens 1995;8:276-281.

40 Shieh SM, Sheu WH, Shen DD, Fuh MM, Jeng CY, Jeng JR, Chen YD, Reaven GM: Improvement in metabolic risk factors for coronary heart disease associated with cilazapril treatment. Am J Hypertens 1992;5:506510.

41 Suzuki M, Ikebuchi M, Yokota C, Shinozaki K, Harano Y: Normalization of insulin resistance in non-obese essential hypertension by cilazapril treatment. Clin Exp Hypertens 1995;17:1257-1268.

-42 Torlone E, Rambotti AM, Perriello G, Botta G, Santeusanio F, Brunetti P, Bolli GB: ACE-inhibition increases hepatic and extrahepatic sensitivity to insulin in patients with type 2 (non-insulin-dependent) diabetes mellitus and arterial hypertension. Diabetologia 1991;34:119-125.

-43 Vuorinen-Markkola H, Yki-Jarvinen H: Antihypertensive therapy with enalapril improves glucose storage and insulin sensitivity in hypertensive patients with non-insulin-dependent diabetes mellitus. Metabolism 1995;44:85-89.

-44 Heinemann L, Heise T, Ampudia J, Sawicki P, Sindelka G, Brunner G, Starke AA: Four week administration of an ACE inhibitor and a cardioselective beta-blocker in healthy volunteers: no influence on insulin sensitivity. Eur J Clin Invest 1995;25:595-600.

$\checkmark 45$ Heise T, Heinemann L, Kristahn K, Berger M, Sawicki PT: Insulin sensitivity in patients with essential hypertension: no influence of the ACE inhibitor enalapril. Horm Metab Res 1999;31:418-423.

-46 Ludvik B, Kueenburg E, Brunnbauer M, Schernthaner G, Prager R: The effects of ramipril on glucose tolerance, insulin secretion, and insulin sensitivity in patients with hypertension. J Cardiovasc Pharmacol 1991;18(suppl 2):S157-159.

47 New JP, Bilous RW, Walker M: Insulin sensitivity in hypertensive type 2 diabetic patients after 1 and 19 days' treatment with trandolapril. Diabet Med 2000;17:134-140.

-48 Petrie JR, Morris AD, Ueda S, Small M, Donnelly R, Connell JM, Elliott HL: Trandolapril does not improve insulin sensitivity in patients with hypertension and type 2 diabetes: a double-blind, placebo-controlled crossover trial. J Clin Endocrinol Metab 2000;85:1882-1889.

49 Pratt MC, Lewis-Barned NJ, Walker RJ: A comparison between enalapril and captopril on insulin sensitivity in normotensive healthy volunteers. Aust N Z J Med 1993;23:652-655.

50 Reaven GM, Clinkingbeard C, Jeppesen J, Maheux P, Pei D, Foote J, Hollenbeck CB, Chen YD: Comparison of the hemodynamic and metabolic effects of low-dose hydrochlorothiazide and lisinopril treatment in obese patients with high blood pressure. Am J Hypertens 1995;8:461-466. 
Goossens et al.: The Renin-Angiotensin System in the Pathophysiology of Type 2 Diabetes

-51 Santoro D, Natali A, Palombo C, Brandi LS, Piatti M, Ghione S, Ferrannini E: Effects of chronic angiotensin converting enzyme inhibition on glucose tolerance and insulin sensitivity in essential hypertension. Hypertension 1992;20:181-191.

-52 Valensi P, Derobert E, Genthon R, Riou JP: Effect of ramipril on insulin sensitivity in obese patients. Timecourse study of glucose infusion rate during euglycaemic hyperinsulinaemic clamp. Diabetes Metab 1996; 22:197-200.

53 Wiggam MI, Hunter SJ, Atkinson AB, Ennis CN, Henry JS, Browne JN, Sheridan B, Bell PM: Captopril does not improve insulin action in essential hypertension: a double-blind placebo-controlled study. J Hypertens 1998;16:1651-1657.

54 Goossens GH, Blaak EE, Schiffers PM, Saris WH, van Baak MA: Effect of short-term ACE inhibitor treatment on peripheral insulin sensitivity in obese insulin-resistant subjects. Diabetologia 2006;49:3009-3016.

-55 DeFronzo RA, Jacot E, Jequier E, Maeder E, Wahren J, Felber JP: The effect of insulin on the disposal of intravenous glucose. Results from indirect calorimetry and hepatic and femoral venous catheterization. Diabetes 1981;30:1000-1007.

56 Barrett EJ, Eggleston EM, Inyard AC, Wang H, Li G, Chai W, Liu Z: The vascular actions of insulin control its delivery to muscle and regulate the rate-limiting step in skeletal muscle insulin action. Diabetologia 2009; 52:752-764.

57 Clerk LH, Vincent MA, Jahn LA, Liu Z, Lindner JR, Barrett EJ: Obesity blunts insulin-mediated microvascular recruitment in human forearm muscle. Diabetes 2006;55:1436-1442.

58 de Jongh RT, Serne EH, RG IJ, de Vries G, Stehouwer CD: Impaired microvascular function in obesity: implications for obesity-associated microangiopathy, hypertension, and insulin resistance. Circulation 2004; 109:2529-2535.

59 Clark MG, Wallis MG, Barrett EJ, Vincent MA, Richards SM, Clerk LH, Rattigan S: Blood flow and muscle metabolism: a focus on insulin action. Am J Physiol Endocrinol Metab 2003;284:E241-258.

60 Vincent MA, Clerk LH, Lindner JR, Klibanov AL, Clark MG, Rattigan S, Barrett EJ: Microvascular recruitment is an early insulin effect that regulates skeletal muscle glucose uptake in vivo. Diabetes 2004;53:14181423.

-61 Wallis MG, Wheatley CM, Rattigan S, Barrett EJ, Clark AD, Clark MG: Insulin-mediated hemodynamic changes are impaired in muscle of Zucker obese rats. Diabetes 2002;51:3492-3498.

62 Baron AD, Clark MG: Role of blood flow in the regulation of muscle glucose uptake. Annu Rev Nutr 1997;17: 487-499.

63 Goossens GH, Blaak EE, Saris WH, Van Baak MA: Angiotensin II-induced effects on adipose and skeletal muscle tissue blood flow and lipolysis in normal-weight and obese subjects. J Clin Endocrinol Metab 2004; 89:2690-2696.

-64 Kodama J, Katayama S, Tanaka K, Itabashi A, Kawazu S, Ishii J: Effect of captopril on glucose concentration. Possible role of augmented postprandial forearm blood flow. Diabetes Care 1990;13:1109-1111.

-65 Chai W, Wang W, Liu J, Barrett EJ, Carey RM, Cao W, Liu Z: Angiotensin II type 1 and type 2 receptors regulate basal skeletal muscle microvascular volume and glucose use. Hypertension 2010;55:523-530.

-66 Rizzoni D, Pasini E, Flati V, Rodella LF, Paiardi S, Assanelli D, De Ciuceis C, Porteri E, Boari GE, Rezzani R, Speca S, Favero G, Martinotti S, Toniato E, Platto C, Agabiti-Rosei E: Angiotensin receptor blockers improve insulin signaling and prevent microvascular rarefaction in the skeletal muscle of spontaneously hypertensive rats. J Hypertens 2008;26:1595-1601.

67 Sabino B, Lessa MA, Nascimento AR, Rodrigues CA, Henriques MG, Garzoni LR, Levy BI, Tibirica E: Effects of antihypertensive drugs on capillary rarefaction in spontaneously hypertensive rats: intravital microscopy and histologic analysis. J Cardiovasc Pharmacol 2008;51:402-409.

-68 Sloniger JA, Saengsirisuwan V, Diehl CJ, Dokken BB, Lailerd N, Lemieux AM, Kim JS, Henriksen EJ: Defective insulin signaling in skeletal muscle of the hypertensive TG(mREN2)27 rat. Am J Physiol Endocrinol Metab 2005;288:E1074-1081.

69 Henriksen EJ, Jacob S, Kinnick TR, Youngblood EB, Schmit MB, Dietze GJ: ACE inhibition and glucose transport in insulin resistant muscle: roles of bradykinin and nitric oxide. Am J Physiol 1999;277:R332-336.

70 Miyata T, Taguchi T, Uehara M, Isami S, Kishikawa H, Kaneko K, Araki E, Shichiri M: Bradykinin potentiates insulin-stimulated glucose uptake and enhances insulin signal through the bradykinin B2 receptor in dog skeletal muscle and rat L6 myoblasts. Eur J Endocrinol 1998;138:344-352.

-71 Ogihara T, Asano T, Ando K, Chiba Y, Sakoda H, Anai M, Shojima N, Ono H, Onishi Y, Fujishiro M, Katagiri H, Fukushima Y, Kikuchi M, Noguchi N, Aburatani H, Komuro I, Fujita T: Angiotensin II-induced insulin resistance is associated with enhanced insulin signaling. Hypertension 2002;40:872-879.

72 Wei Y, Sowers JR, Clark SE, Li W, Ferrario CM, Stump CS: Angiotensin II-induced skeletal muscle insulin resistance mediated by NF-kappaB activation via NADPH oxidase. Am J Physiol Endocrinol Metab 2008; 294:E345-351.

-73 Marchionne EM, Diamond-Stanic MK, Prasonnarong M, Henriksen EJ: Chronic renin inhibition with aliskiren improves glucose tolerance, insulin sensitivity, and skeletal muscle glucose transport activity in obese Zucker rats. Am J Physiol Regul Integr Comp Physiol 2012;302:R137-142.

-74 Lastra G, Habibi J, Whaley-Connell AT, Manrique C, Hayden MR, Rehmer J, Patel K, Ferrario C, Sowers JR: Direct renin inhibition improves systemic insulin resistance and skeletal muscle glucose transport in a transgenic rodent model of tissue renin overexpression. Endocrinology 2009;150:2561-2568. 
Goossens et al.: The Renin-Angiotensin System in the Pathophysiology of Type 2 Diabetes

75 Lastra G, Whaley-Connell A, Manrique C, Habibi J, Gutweiler AA, Appesh L, Hayden MR, Wei Y, Ferrario C, Sowers JR: Low-dose spironolactone reduces reactive oxygen species generation and improves insulinstimulated glucose transport in skeletal muscle in the TG(mRen2)27 rat. Am J Physiol Endocrinol Metab 2008;295:E110-116.

-76 Iwai M, Kanno H, Tomono Y, Inaba S, Senba I, Furuno M, Mogi M, Horiuchi M: Direct renin inhibition improved insulin resistance and adipose tissue dysfunction in type 2 diabetic KK-A(y) mice. J Hypertens 2010;28: 1471-1481.

77 Kang YS, Lee MH, Song HK, Hyun YY, Cha JJ, Ko GJ, Kim SH, Lee JE, Han JY, Cha DR: Aliskiren improves insulin resistance and ameliorates diabetic vascular complications in db/db mice. Nephrol Dial Transplant 2011; 26:1194-1204.

78 Schrauwen P, Schrauwen-Hinderling V, Hoeks J, Hesselink MK: Mitochondrial dysfunction and lipotoxicity. Biochim Biophys Acta 2010;1801:266-271.

-79 Anderson EJ, Lustig ME, Boyle KE, Woodlief TL, Kane DA, Lin CT, Price JW 3rd, Kang L, Rabinovitch PS, Szeto HH, Houmard JA, Cortright RN, Wasserman DH, Neufer PD: Mitochondrial H2O2 emission and cellular redox state link excess fat intake to insulin resistance in both rodents and humans. J Clin Invest 2009;119: 573-581.

-80 Bonnard C, Durand A, Peyrol S, Chanseaume E, Chauvin MA, Morio B, Vidal H, Rieusset J: Mitochondrial dysfunction results from oxidative stress in the skeletal muscle of diet-induced insulin-resistant mice. J Clin Invest 2008;118:789-800.

81 Lee HY, Choi CS, Birkenfeld AL, Alves TC, Jornayvaz FR, Jurczak MJ, Zhang D, Woo DK, Shadel GS, Ladiges W, Rabinovitch PS, Santos JH, Petersen KF, Samuel VT, Shulman GI: Targeted expression of catalase to mitochondria prevents age-associated reductions in mitochondrial function and insulin resistance. Cell Metab 2010;12:668-674.

-82 Mitsuishi M, Miyashita K, Muraki A, Itoh H: Angiotensin II reduces mitochondrial content in skeletal muscle and affects glycemic control. Diabetes 2009;58:710-717.

83 Goossens GH: The role of adipose tissue dysfunction in the pathogenesis of obesity-related insulin resistance. Physiol Behav 2008;94:206-218.

84 Engeli S, Gorzelniak K, Kreutz R, Runkel N, Distler A, Sharma AM: Co-expression of renin-angiotensin system genes in human adipose tissue. J Hypertens 1999;17:555-560.

85 Jones BH, Standridge MK, Taylor JW, Moustaid N: Angiotensinogen gene expression in adipose tissue: analysis of obese models and hormonal and nutritional control. Am J Physiol 1997;273:R236-242.

-86 Karlsson C, Lindell K, Ottosson M, Sjostrom L, Carlsson B, Carlsson LM: Human adipose tissue expresses angiotensinogen and enzymes required for its conversion to angiotensin II. J Clin Endocrinol Metab 1998; 83:3925-3929.

-87 Schling P, Mallow H, Trindl A, Loffler G: Evidence for a local renin angiotensin system in primary cultured human preadipocytes. Int J Obes Relat Metab Disord 1999;23:336-341.

$\checkmark 88$ Schling P, Schafer T: Human adipose tissue cells keep tight control on the angiotensin II levels in their vicinity. J Biol Chem 2002;277:48066-48075.

89 Crandall DL, Herzlinger HE, Saunders BD, Armellino DC, Kral JG: Distribution of angiotensin II receptors in rat and human adipocytes. J Lipid Res 1994;35:1378-1385.

-90 Goossens GH, Jocken JW, Blaak EE, Schiffers PM, Saris WH, van Baak MA: Endocrine role of the renin-angiotensin system in human adipose tissue and muscle: effect of beta-adrenergic stimulation. Hypertension 2007;49:542-547.

-91 Goossens GH, Bizzarri A, Venteclef N, Essers Y, Cleutjens JP, Konings E, Jocken JW, Cajlakovic M, Ribitsch V, Clement K, Blaak EE: Increased adipose tissue oxygen tension in obese compared with lean men is accompanied by insulin resistance, impaired adipose tissue capillarization, and inflammation. Circulation 2011; 124:67-76.

-92 Eriksson JW, Smith U, Waagstein F, Wysocki M, Jansson PA: Glucose turnover and adipose tissue lipolysis are insulin-resistant in healthy relatives of type 2 diabetes patients: is cellular insulin resistance a secondary phenomenon? Diabetes 1999;48:1572-1578.

$\$ 93$ Paolisso G, Tataranni PA, Foley JE, Bogardus C, Howard BV, Ravussin E: A high concentration of fasting plasma non-esterified fatty acids is a risk factor for the development of NIDDM. Diabetologia 1995;38: 1213-1217.

-94 Weyer C, Foley JE, Bogardus C, Tataranni PA, Pratley RE: Enlarged subcutaneous abdominal adipocyte size, but not obesity itself, predicts type II diabetes independent of insulin resistance. Diabetologia 2000;43: 1498-1506.

95 Lundgren M, Svensson M, Lindmark S, Renstrom F, Ruge T, Eriksson JW: Fat cell enlargement is an independent marker of insulin resistance and 'hyperleptinaemia'. Diabetologia 2007;50:625-633.

$\$ 96$ Frayn KN: Adipose tissue and the insulin resistance syndrome. Proc Nutr Soc 2001;60:375-380.

$\$ 97$ Janke J, Engeli S, Gorzelniak K, Luft FC, Sharma AM: Mature adipocytes inhibit in vitro differentiation of human preadipocytes via angiotensin type 1 receptors. Diabetes 2002;51:1699-1707.

-98 Saiki A, Koide N, Watanabe F, Murano T, Miyashita Y, Shirai K: Suppression of lipoprotein lipase expression in 3T3-L1 cells by inhibition of adipogenic differentiation through activation of the renin-angiotensin system. Metabolism 2008;57:1093-1100. 
Goossens et al.: The Renin-Angiotensin System in the Pathophysiology of Type 2 Diabetes

-99 Furuhashi M, Ura N, Takizawa H, Yoshida D, Moniwa N, Murakami H, Higashiura K, Shimamoto K: Blockade of the renin-angiotensin system decreases adipocyte size with improvement in insulin sensitivity. J Hypertens 2004;22:1977-1982.

100 Munoz MC, Giani JF, Dominici FP, Turyn D, Toblli JE: Long-term treatment with an angiotensin II receptor blocker decreases adipocyte size and improves insulin signaling in obese Zucker rats. J Hypertens 2009; 27:2409-2420.

101 Tomono Y, Iwai M, Inaba S, Mogi M, Horiuchi M: Blockade of AT1 receptor improves adipocyte differentiation in atherosclerotic and diabetic models. Am J Hypertens 2008;21:206-212.

102 Goossens GH, Moors CCM, van der Zijl NJ, Venteclef N, Alili R, Jocken JWE, Essers Y, Cleutjens JP, Clément K, Diamant K, Blaak EE: Valsartan improves adipose tissue function in humans with impaired glucose metabolism: a randomized placebo-controlled double-blind trial. PLoS ONE 2012; 7:e39930.

103 Benson SC, Pershadsingh HA, Ho CI, Chittiboyina A, Desai P, Pravenec M, Qi N, Wang J, Avery MA, Kurtz TW: Identification of telmisartan as a unique angiotensin II receptor antagonist with selective PPARgammamodulating activity. Hypertension 2004;43:993-1002.

104 Schupp M, Janke J, Clasen R, Unger T, Kintscher U: Angiotensin type 1 receptor blockers induce peroxisome proliferator-activated receptor-gamma activity. Circulation 2004;109:2054-2057.

105 Kintscher U, Foryst-Ludwig A, Unger T: Inhibiting angiotensin type 1 receptors as a target for diabetes. Expert Opin Ther Targets 2008;12:1257-1263.

106 Jones BH, Standridge MK, Moustaid N: Angiotensin II increases lipogenesis in 3T3-L1 and human adipose cells. Endocrinology 1997;138:1512-1519.

107 Boschmann M, Ringel J, Klaus S, Sharma AM: Metabolic and hemodynamic response of adipose tissue to angiotensin II. Obes Res 2001;9:486-491.

108 Boschmann M, Rosenbaum M, Leibel RL, Segal KR: Metabolic and hemodynamic responses to exercise in subcutaneous adipose tissue and skeletal muscle. Int J Sports Med 2002;23:537-543.

109 Goossens GH, Blaak EE, Arner P, Saris WH, van Baak MA: Angiotensin II: a hormone that affects lipid metabolism in adipose tissue. Int J Obes (Lond) 2007;31:382-384.

110 Boschmann M, Adams F, Klaus S, Sharma AM, Luft FC, Jordan J: Differential response to interstitial angiotensin II in normal weight and obese men. Int J Obes Relat Metab Disord 2003;27(suppl):S52.

111 Boschmann M, Adams F, Schaller K, Franke G, Sharma AM, Klaus S, Luft FC, Jordan J: Hemodynamic and metabolic responses to interstitial angiotensin II in normal weight and obese men. J Hypertens 2006;24: 1165-1171.

112 Boschmann M, Kreuzberg U, Engeli S, Adams F, Franke G, Klaua S, Scholze J, Weidinger G, Luft FC, Sharma AM, Jordan J: The effect of oral glucose loads on tissue metabolism during angiotensin II receptor and betareceptor blockade in obese hypertensive subjects. Horm Metab Res 2006;38:323-329.

-113 Lee MH, Song HK, Ko GJ, Kang YS, Han SY, Han KH, Kim HK, Han JY, Cha DR: Angiotensin receptor blockers improve insulin resistance in type 2 diabetic rats by modulating adipose tissue. Kidney Int 2008;74:890900.

114 Kurata A, Nishizawa H, Kihara S, Maeda N, Sonoda M, Okada T, Ohashi K, Hibuse T, Fujita K, Yasui A, Hiuge A, Kumada M, Kuriyama H, Shimomura I, Funahashi T: Blockade of Angiotensin II type-1 receptor reduces oxidative stress in adipose tissue and ameliorates adipocytokine dysregulation. Kidney Int 2006;70:17171724 .

115 Pscherer S, Heemann U, Frank H: Effect of renin-angiotensin system blockade on insulin resistance and inflammatory parameters in patients with impaired glucose tolerance. Diabetes Care 2010;33:914-919.

-116 Furuhashi M, Ura N, Higashiura K, Murakami H, Tanaka M, Moniwa N, Yoshida D, Shimamoto K: Blockade of the renin-angiotensin system increases adiponectin concentrations in patients with essential hypertension. Hypertension 2003;42:76-81.

117 Tian F, Luo R, Zhao Z, Wu Y, Ban D: Blockade of the RAS increases plasma adiponectin in subjects with metabolic syndrome and enhances differentiation and adiponectin expression of human preadipocytes. Exp Clin Endocrinol Diabetes 2010;118:258-265.

118 Yilmaz MI, Sonmez A, Caglar K, Celik T, Yenicesu M, Eyileten T, Acikel C, Oguz Y, Yavuz I, Vural A: Effect of antihypertensive agents on plasma adiponectin levels in hypertensive patients with metabolic syndrome. Nephrology (Carlton) 2007;12:147-153.

119 Fliser D, Buchholz K, Haller H: Antiinflammatory effects of angiotensin II subtype 1 receptor blockade in hypertensive patients with microinflammation. Circulation 2004;110:1103-1107.

$\checkmark 120$ Aksnes TA, Seljeflot I, Torjesen PA, Hoieggen A, Moan A, Kjeldsen SE: Improved insulin sensitivity by the angiotensin II-receptor blocker losartan is not explained by adipokines, inflammatory markers, or whole blood viscosity. Metabolism 2007;56:1470-1477.

121 Goossens GH, McQuaid SE, Dennis AL, van Baak MA, Blaak EE, Frayn KN, Saris WH, Karpe F: Angiotensin II: a major regulator of subcutaneous adipose tissue blood flow in humans. J Physiol 2006;571:451-460.

122 Karpe F, Fielding BA, Ilic V, Macdonald IA, Summers LK, Frayn KN: Impaired postprandial adipose tissue blood flow response is related to aspects of insulin sensitivity. Diabetes 2002;51:2467-2473.

123 Jansson PA, Larsson A, Lonnroth PN: Relationship between blood pressure, metabolic variables and blood flow in obese subjects with or without non-insulin-dependent diabetes mellitus. Eur J Clin Invest 1998;28: 813-818. 
124 Blaak EE, van Baak MA, Kemerink GJ, Pakbiers MT, Heidendal GA, Saris WH: Beta-adrenergic stimulation and abdominal subcutaneous fat blood flow in lean, obese, and reduced-obese subjects. Metabolism 1995; 44:183-187.

125 Samra JS, Simpson EJ, Clark ML, Forster CD, Hu mphreys SM, Macdonald IA, Frayn KN: Effects of epinephrine infusion on adipose tissue: interactions between blood flow and lipid metabolism. Am J Physiol 1996; 271:E834-839.

126 Edens NK, Leibel RL, Hirsch J: Mechanism of free fatty acid re-esterification in human adipocytes in vitro. J Lipid Res 1990;31:1423-1431.

127 Trayhurn P, Wood IS: Adipokines: inflammation and the pleiotropic role of white adipose tissue. Br J Nutr 2004;92:347-355.

128 Hosogai N, Fukuhara A, Oshima K, Miyata Y, Tanaka S, Segawa K, Furukawa S, Tochino Y, Komuro R, Matsuda M, Shimomura I: Adipose tissue hypoxia in obesity and its impact on adipocytokine dysregulation. Diabetes 2007;56:901-911.

129 Ye J, Gao Z, Yin J, He Q: Hypoxia is a potential risk factor for chronic inflammation and adiponectin reduction in adipose tissue of ob/ob and dietary obese mice. Am J Physiol Endocrinol Metab 2007;293:E1118-1128.

130 Chen B, Lam KS, Wang Y, Wu D, Lam MC, Shen J, Wong L, Hoo RL, Zhang J, Xu A: Hypoxia dysregulates the production of adiponectin and plasminogen activator inhibitor-1 independent of reactive oxygen species in adipocytes. Biochem Biophys Res Commun 2006;341:549-556.

131 Wang B, Wood IS, Trayhurn P: Dysregulation of the expression and secretion of inflammation-related adipokines by hypoxia in human adipocytes. Pflugers Arch 2007;455:479-492.

132 Rausch ME, Weisberg S, Vardhana P, Tortoriello DV: Obesity in C57BL/6J mice is characterized by adipose tissue hypoxia and cytotoxic T-cell infiltration. Int J Obes 2008;32:451-463.

133 Kabon B, Nagele A, Reddy D, Eagon C, Fleshman JW, Sessler DI, Kurz A: Obesity decreases perioperative tissue oxygenation. Anesthesiology 2004;100:274-280.

134 Pasarica M, Sereda OR, Redman LM, Albarado DC, Hymel DT, Roan LE, Rood JC, Burk DH, Smith SR: Reduced adipose tissue oxygenation in human obesity: evidence for rarefaction, macrophage chemotaxis, and inflammation without an angiogenic response. Diabetes 2009;58:718-725. 